\title{
Solución del caso. Apendicitis del muñón apendicular. Reporte de un caso
}

\author{
Viene de la página 417
}

\section{Solución del caso}

Por los hallazgos obtenidos en las imágenes, se decide la realización de una punción evacuadora y diagnóstica guiada por una ecografía. Se obtiene material purulento del que se aísla la Escherichia Coli, por lo que se procede a la intervención quirúrgica.

Durante la misma, se evidencia al nivel del ciego un remanente apendicular de aproximadamente $0,5 \mathrm{~cm}$ con cambios isquémicos y una colección purulenta asociada. El estudio histopatológico confirma una apendicitis del muñón.

La apendicitis del muñón es una patología descripta por primera vez por Rose en $1945 .{ }^{3}$ La principal causa es la presencia de una parte no extirpada (o resecada) del apéndice cecal, la cual pasa por un proceso de inflamación e infección con su posterior isquemia y perforación. ${ }^{1}$ Este fragmento apendicular no extirpado se puede relacionar con una alteración anatómica del apéndice cecal, donde su base es más amplia y se confunde con parte del ciego, con un apéndice duplicado o se debe a una inadecuada sección que dejó un remanente apendicular (muñón) largo. ${ }^{1,2}$

Los métodos imagenológicos juegan un papel trascendental en el diagnóstico de esta enfermedad, permitién- donos correlacionar la sintomatología con los hallazgos descriptos. $^{2}$ La ecografía del abdomen nos proporciona imágenes características del proceso inflamatorio e infeccioso perilesional; además de ser un método no invasivo, económico y asequible.

La tomografía computada nos ayuda a su detección cuando la ecografía no es concluyente. Nos muestra una delineación exacta de sus características anatómicas, la presencia de un absceso o flemón pericecal y nos facilita el seguimiento clínico, realizando un diagnóstico más precoz de esta enfermedad y evitando su evolución a estadios graves.

\section{Referencias}

1. Dikicier E, Altintoprak F, Ozdemir K, Gundogdu K, Uzunoglu MY, Cakmak G, Onuray F, Capoglu R. Stump appendicitis: a retrospective review of 3130 consecutive appendectomy cases. World J Emerg Surg 2018; 13: 22. Doi: 10.1186/s13017-018-0182-5.

2. Subramanian A, Liang MK. "A 60-year literature review of stump appendicitis: the need for a critical view". American journal of surgery 2012; 203 (4): 503-507. Doi: 10.1016/j.amjsurg.2011.04.009.

3. Balogun OS, Osinowo AO, Makanjuola AA, Nwokocha SO. Stump Appendicitis due to Retained Fecalith after Laparoscopic Surgery. Niger Med J 2019; 60 (2): 92-94. Doi: 10.4103/nmj.NMJ_39_19. 